\title{
Influence of species/cultivar and season on the quality of Atriplex grown at different sites in South Africa
}

\author{
W.A. van Niekerk ${ }^{\#}$, Abubeker Hassen, P.J. Vermaak and R.J. Coertze \\ Department of Animal \& Wildlife Sciences, University of Pretoria, Pretoria 0002, South Africa
}

\begin{abstract}
Atriplex species/cultivars [Atriplex nummularia, A. canescens (Santa Rita) and A. canescens (Field Reserve 1)] were compared in terms of chemical composition and in vitro digestibility. The plant material was sampled at different seasons (autumn and winter) and from different sites (Hatfield in the Gauteng Province and Mier and Lovedale, both in the Northern Cape Province) and were analysed for crude protein (CP), neutral detergent fibre (NDF) and in vitro digestibility (IVOMD). The CP and IVOMD of the leaves were higher than the stem for the Atriplex species. Leaf percentage for the autumn samples was not affected by species at Hatfield and Mier, but $A$. canescens (Field Reserve 1) had lower leaf percentage at Lovedale as well as for winter samples at Hatfield. At Lovedale, however, A. nummularia had the highest leaf : stem ratio compared to A. canescens (Santa Rita) and A. canescens (Field Reserve 1). Atriplex nummularia had a higher $\mathrm{CP}$ concentration than A. canescens (Field Reserve 1) and A. canescens (Santa Rita) at both Mier and Lovedale, but species/cultivar had no effect on CP concentration at Hatfield. Autumn samples had a higher $\mathrm{CP}$ concentration than winter samples at both Mier and Lovedale, but season had no effect on the $\mathrm{N}$ concentration at Hatfield. Atriplex nummularia had a lower NDF and higher IVOMD concentration compared to A. canescens (Santa Rita) and A. canescens (Field Reserve 1). Autumn samples were less fibrous and more digestible than winter samples. Atriplex nummularia seems to be better in terms of its nutritive value compared to $A$. canescens (Santa Rita) and A. canescens (Field Reserve 1), with better quality forage in autumn than winter.
\end{abstract}

Keywords: Chemical composition, drought tolerant, fodder, salt bush, shrubs

${ }^{\#}$ Corresponding author. E-mail: willem.vanniekerk@up.ac.za

\section{Introduction}

In semi-arid and arid rangelands of South Africa forage availability and quality is often limiting due to extremely low rainfall and drought conditions. In these areas Atriplex species has been identified as adaptable species that produce good fodder to increase animal production. The adaptability is mainly due to their ability to tolerate drought and salinity (Le Houérou, 1992, Malan, 2000). However, the nutritive value is related to the palatability of the fodder for a given animal type, which in turn is affected by phenological stage at harvest, plant parts and season of use (Squires \& Ayoub, 1992). At an earlier stage of evaluation, the nutritive value of the feed could be ranked based on chemical composition and in vivo digestibility of the forage. This study was undertaken to compare Atriplex species/cultivars on the basis of their chemical composition and in vitro digestibility when harvested at different seasons from different sites.

\section{Material and Methods}

Atriplex species/cultivars (Atriplex nummularia, A. canescens Santa Rita and A. canescens Field Reserve 1) were established at three sites (Hatfield in the Gauteng Province and Mier and Lovedale, both in the Northern Cape Province) and the plant materials were harvested both during the autumn and winter season. It was separated into leaf and stem material and then dried in a forced draught oven at $60{ }^{\circ} \mathrm{C}$ for 24 hours. The percentage of leaf material was determined. Representative samples of the edible forage harvest were analysed for crude protein (CP) according to AOAC (2000), NDF according to Robertson \& Van Soest (1970) and in vitro organic matter digestibility (IVOMD) according to Tilley \& Terry (1963) as modified by Engels \& Van der Merwe (1967).

Analysis of variance with the Proc GLM model (SAS, 2001) was used to determine the significance between different species/cultivars, sites, seasons and plant parts. Least square means and standard errors 
were calculated for main effects where there was no significant interaction effect. A difference between means was declared by Bonferroni’s test (Samuels, 1989).

\section{Results and Discussion}

Generally, regardless of the location, the CP and IVOMD of the leaves were significantly higher than that of the stem for all Atriplex species (Table 1). This is in agreement with Wilcock et al. (2004) who found higher CP and IVOMD in the leaves than in the stems for three browse species.

Table 1 Crude protein and in vitro organic matter digestibility (IVOMD) of leaf and stem fractions of Atriplex species/cultivars grown at different locations

\begin{tabular}{|c|c|c|c|c|c|}
\hline \multirow[b]{2}{*}{ Parameter } & \multirow[b]{2}{*}{ Location } & \multirow[b]{2}{*}{ Plant fraction } & \multicolumn{3}{|c|}{ Atriplex species/cultivars } \\
\hline & & & $\begin{array}{l}\text { A. canescens } \\
\text { (Santa Rita) }\end{array}$ & $\begin{array}{l}\text { A. canescens } \\
\text { (Field Reserve 1) }\end{array}$ & A. nummularia \\
\hline \multirow[t]{3}{*}{$\begin{array}{l}\text { CP } \\
\text { (g/kg DM) }\end{array}$} & Hatfield & $\begin{array}{l}\text { Leaves } \\
\text { Stem }\end{array}$ & $\begin{array}{l}148^{\mathrm{a}} \pm 19 \\
72^{\mathrm{b}}{ }_{1,2} \pm 8\end{array}$ & $\begin{array}{l}133^{\mathrm{a}} \pm 25 \\
55^{\mathrm{b}}{ }_{1} \pm 9\end{array}$ & $\begin{array}{l}156^{\mathrm{a}} \pm 8 \\
91_{2}^{\mathrm{b}} \pm 13\end{array}$ \\
\hline & Mier & $\begin{array}{l}\text { Leaves } \\
\text { Stem }\end{array}$ & $\begin{array}{l}187^{\mathrm{a}}{ }_{1} \pm 26 \\
99^{\mathrm{b}}{ }_{1} \pm 12\end{array}$ & $\begin{array}{l}206^{\mathrm{a}}{ }_{1} \pm 37 \\
91^{\mathrm{b}}{ }_{1} \pm 17\end{array}$ & $\begin{array}{l}256^{\mathrm{a}}{ }_{2} \pm 26 \\
133^{\mathrm{b}}{ }_{2} \pm 30\end{array}$ \\
\hline & Lovedale & $\begin{array}{l}\text { Leaves } \\
\text { Stem }\end{array}$ & $\begin{array}{l}178^{\mathrm{a}}{ }_{1 \pm 2} \pm 26 \\
75^{\mathrm{b}}{ }_{1} \pm 11\end{array}$ & $\begin{array}{l}167^{\mathrm{a}}{ }_{1} \pm 28 \\
72^{\mathrm{b}}{ }_{1} \pm 19\end{array}$ & $\begin{array}{l}239^{\mathrm{a}}{ }_{2} \pm 27 \\
128^{\mathrm{b}}{ }_{2} \pm 17\end{array}$ \\
\hline \multirow[t]{3}{*}{$\begin{array}{l}\text { IVOMD } \\
\text { (g/kg DM) }\end{array}$} & Hatfield & $\begin{array}{l}\text { Leaves } \\
\text { Stem }\end{array}$ & $\begin{array}{l}685^{\mathrm{a}} \pm 28 \\
249^{\mathrm{b}} \pm 28\end{array}$ & $\begin{array}{l}681^{\mathrm{a}} \pm 51 \\
245^{\mathrm{b}}{ }_{2} \pm 49\end{array}$ & $\begin{array}{l}648^{\mathrm{a}} \pm 47 \\
327^{\mathrm{b}}{ }_{1} \pm 30\end{array}$ \\
\hline & Mier & $\begin{array}{l}\text { Leaves } \\
\text { Stem }\end{array}$ & $\begin{array}{l}663^{\mathrm{a}} \pm 113 \\
329^{\mathrm{b}} \pm 38\end{array}$ & $\begin{array}{l}749^{\mathrm{a}} \pm 57 \\
258^{\mathrm{b}} \pm 62\end{array}$ & $\begin{array}{l}774^{\mathrm{a}} \pm 47 \\
424^{\mathrm{b}} \pm 104\end{array}$ \\
\hline & Lovedale & $\begin{array}{l}\text { Leaves } \\
\text { Stem }\end{array}$ & $\begin{array}{l}672^{\mathrm{a}}{ }_{1} \pm 77 \\
277^{\mathrm{b}}{ }_{1} \pm 64\end{array}$ & $\begin{array}{l}685^{\mathrm{a}}{ }_{1,2} \pm 75 \\
256^{\mathrm{b}}{ }_{1} \pm 96\end{array}$ & $\begin{array}{l}775^{\mathrm{a}}{ }_{2} \pm 120 \\
406^{\mathrm{b}}{ }_{2} \pm 47\end{array}$ \\
\hline
\end{tabular}

${ }^{\mathrm{a}, \mathrm{b}}$ means within a column followed by different superscripts differ at $\mathrm{P}<0.05$.

${ }_{1,2}$ means within a row followed by different subscripts differ at $\mathrm{P}<0.05$.

The interaction effect between species/cultivars, season and sites were significant for the leaf percentages. Percentage of leaf for the autumn sample was not affected by species/cultivar in Hatfield and Mier, but in Lovedale A. canescens (Field Reserve 1) had a lower leaf percentage compared to the other two Atriplex species/cultivars (Table 2). For winter samples, A. canescens (Field Reserve 1) had the lowest leaf percentage compared to the rest of the samples collected from Hatfield and Mier. At Lovedale, however, $A$. nummularia had the highest leaf percentage compared to the other two A. canescens species.

The interaction effect between species/cultivars and site as well as between season and site were significant for CP concentration of the edible forage material (Tables 3 and 4). A. nummularia had a higher CP concentration than A. canescens in samples collected from both Mier and Lovedale, but the difference between the species was not significant in Hatfield. The CP values recorded in Hatfield for both $A$. canescens spp. and A. nummularia were lower than the $\mathrm{CP}$ values reported for the respective species by Benjamin et al. (1995) whereas in Mier and Lovedale the CP values were higher than that reported by Benjamin et al. (1995). Autumn samples had a higher CP concentration than winter samples for samples collected from Mier and Lovedale, but season had no effect on the $\mathrm{N}$ concentration of samples collected from Hatfield.

There was no interaction effect between species/cultivars, season and site in terms of the NDF and IVOMD of the samples. However, the main effects of species/cultivars, season and sites were significant for NDF and IVOMD concentrations of the edible components. Generally A. nummularia had lower NDF and 
Table 2 Interaction effects between species/cultivars, season and location on the percentage of leaf material of certain Atriplex shrubs

\begin{tabular}{lllll}
\hline \multirow{2}{*}{ Location } & Season & \multicolumn{3}{c}{ Atriplex species/cultivars } \\
\cline { 3 - 5 } & $\begin{array}{l}\text { A. canescens } \\
\text { (Santa Rita) }\end{array}$ & $\begin{array}{l}\text { A. canescens } \\
\text { (Field Reserve 1) }\end{array}$ & A. nummularia \\
\hline \multirow{2}{*}{ Hatfield } & Autumn & $55.5 \pm 4.81$ & $44.5^{\mathrm{a}} \pm 4.81$ & $53.6 \pm 4.81$ \\
& Winter & $51.5_{1} \pm 4.81$ & $27.4^{\mathrm{b}}{ }_{2} \pm 4.81$ & $54.7_{1} \pm 4.81$ \\
\multirow{3}{*}{ Mier } & & $73.2 \pm 4.81$ & $68.5^{\mathrm{a}} \pm 4.81$ & $72.7 \pm 4.81$ \\
& Autumn & $78.9_{1} \pm 4.81$ & $44.6^{\mathrm{b}}{ }_{3} \pm 4.81$ & $64.2_{2} \pm 4.81$ \\
\multirow{2}{*}{ Lovedale } & Winter & $69.1^{\mathrm{a}} \pm 4.81$ & $51.3^{\mathrm{a}}{ }^{2} \pm 4.81$ & $65.8_{1} \pm 4.81$ \\
& Autumn & $50.1^{\mathrm{b}}{ }_{2} \pm 4.81$ & $36.8^{\mathrm{b}}{ }_{2} \pm 4.81$ & $74.6_{1} \pm 4.81$ \\
& Winter & & & \\
\hline
\end{tabular}

$\overline{\mathrm{a}, \mathrm{b}}$ means within a column followed by different superscripts differ at $\mathrm{P}<0.05$.

1,2 means within a row followed by different subscripts differ at $\mathrm{P}<0.05$.

Table 3 Interaction effects of species and location on the crude protein $(\mathrm{g} / \mathrm{kg} \mathrm{DM})$ concentration of three Atriplex species

\begin{tabular}{llll}
\hline \multirow{2}{*}{ Species/cultivars } & \multicolumn{3}{c}{ Location } \\
\cline { 2 - 4 } & Hatfield & Mier & Lovedale \\
\hline A. canescens (Santa Rita) & $148_{2} \pm 8.3$ & $187^{\mathrm{b}}{ }^{\mathrm{b}} \pm 8.3$ & $178^{\mathrm{b}}{ } \pm 8.3$ \\
A. canescens (Field Reserve 1) & $133_{2} \pm 8.3$ & $206^{\mathrm{b}}{ }^{\mathrm{b}} \pm 8.3$ & $167^{\mathrm{b}}{ } \pm 8.3$ \\
A. nummularia & $156_{2} \pm 8.3$ & $256^{\mathrm{a}}{ }_{1} \pm 8.3$ & $239^{\mathrm{a}}{ }_{1} \pm 8.3$
\end{tabular}

\footnotetext{
${ }^{\mathrm{a}, \mathrm{b}}$ means within a column followed by different superscripts differ at $\mathrm{P}<0.05$.

1,2 means within a row followed by different subscripts differ at $\mathrm{P}<0.05$.
}

Table 4 Interaction effects of season and location on the crude protein (g/kg DM) concentration of Atriplex species

\begin{tabular}{llcc}
\hline \multirow{2}{*}{ Season } & \multicolumn{3}{c}{ Location } \\
\cline { 2 - 4 } & Hatfield & Mier & Lovedale \\
\hline \multirow{2}{*}{ Autumn } & $141_{3} \pm 6.8$ & $235^{\mathrm{a}}{ }_{1} \pm 6.8$ & $209^{\mathrm{a}}{ }_{2} \pm 6.8$ \\
Winter & $150_{2} \pm 6.8$ & $198^{\mathrm{b}}{ }_{1} \pm 6.8$ & $179^{\mathrm{b}}{ }_{1 \pm 6.8}$ \\
\hline
\end{tabular}

${ }^{\mathrm{a}, \mathrm{b}}$ means within a column followed by different superscripts differ at $\mathrm{P}<0.05$.
.

higher IVOMD concentrations compared to A. canescens (Santa Rita), but the differences between IVOMD of A. nummularia and A. canescens (Field Reserve 1) were not significant (Table 5). Benjamin et al. (1995) also reported a higher IVOMD for A. nummularia compared to A. canescens. In contrast to our study, Watson (1990) found higher NDF concentrations in A. nummularia compared to A. canescens. Autumn samples were less fibrous and more digestible than winter materials. Among the sites, samples collected from Hatfield were more fibrous and less digestible compared to those collected from Mier and Lovedale. The exception was for the IVOMD concentration that was not significantly different between Hatfield and Lovedale samples. 
Table 5 Average influence of species/cultivars, season and site on the NDF (g/kg DM) concentration and in vitro digestibility (g/kg DM) of Atriplex shrubs

\begin{tabular}{lll}
\hline Variable & $\begin{array}{l}\text { NDF concentration } \\
(\mathrm{g} / \mathrm{kg} \mathrm{DM})\end{array}$ & $\begin{array}{l}\text { In vitro digestibility } \\
(\mathrm{g} / \mathrm{kg} \mathrm{DM})\end{array}$ \\
\hline Species/cultivars & & \\
$\quad$ A. canescens (Santa Rita) & $531.3^{\mathrm{b}} \pm 11.74$ & $673.4^{\mathrm{b}} \pm 17.29$ \\
$\quad \begin{array}{l}\text { A. canescens (Field Reserve 1) } \\
\text { A. nummularia }\end{array}$ & $605.7^{\mathrm{a}} \pm 11.74$ & $704.8^{\mathrm{ab}} \pm 17.29$ \\
& $491.7^{\mathrm{c}} \pm 11.74$ & $732.4^{\mathrm{a}} \pm 17.29$ \\
Season & & \\
$\quad$ Autumn & $511.2^{\mathrm{b}} \pm 9.59$ & $720.1^{\mathrm{a}} \pm 14.12$ \\
$\quad$ Winter & $574.5^{\mathrm{a}} \pm 9.59$ & $687.0^{\mathrm{b}} \pm 14.12$ \\
& & \\
Site $\quad$ & $671.2^{\mathrm{b}} \pm 17.29$ \\
$\quad$ Hatfield & $618.8^{\mathrm{a}} \pm 11.74$ & $728.7^{\mathrm{a}} \pm 17.29$ \\
$\quad$ Mier & $480.6^{\mathrm{c}} \pm 11.74$ & $710.7^{\mathrm{ab}} \pm 17.29$ \\
$\quad$ Lovedale & $529.3^{\mathrm{b}} \pm 11.74$ & \\
\hline a,b & &
\end{tabular}

\section{Conclusion}

A. nummularia had a higher crude protein concentration than the two A. canescens species in the Northern Cape where the autumn samples were also higher in CP than the winter samples. Atriplex nummularia had lower NDF and higher IVOMD concentrations than the two A. canescens species, resulting in a higher nutritive value. As expected, the leaves had higher CP and IVOMD values than the stems.

\section{References}

AOAC, 2000. Official Methods of Analysis (17th ed.). Association of Official Analytical Chemists, Inc., Arlington, Virginia, USA.

Benjamin, R.W., Lavie, Y., Forti, M., Barkai, D., Yonatan, R. \& Hefetez, Y., 1995. Annual regrowth and edible biomass of two species of Atriplex and Cassia sturtii after browsing. J. Arid. Envirn. 29, 63-84.

Engels, E.A.N. \& Van der Merwe, F.J., 1967. Application of an in vitro technique to South African forages with special reference to the effect of certain factors on the result. S. Afr. J. Agric. Sci. 10, 983-995.

Le Houérou, H.N., 1992. The role of saltbushes (Atriplex spp.) in arid land rehabilitation in the Mediterranean basin: a review. Agroforestry Sys. 18, 107-148.

Malan, P.J., 2000. Selection and propagation of elite Atriplex material. M.Sc. Agric. dissertation, University of Pretoria, South Africa.

Robertson, J.B. \& Van Soest, P.J., 1981. The detergent system of analysis and its application to human foods. In: The Analysis of Dietary Fiber in Food. Eds James, W.P.T. \& Theander, O., Marcel Dekker, New York. pp. 123-158.

Samuels, M.L., 1989. Statistics for Life Sciences. Collier Macmillan Publishers, London, UK.

SAS, 2001. Institute Inc., SAS/STAT User's Guide, Version 6, Fourth Edition, Volume 1, Cary, N.C., SAS Institute INC. p. 943.

Squires, V.R. \& Ayoub, A.L., 1992. Halophytes as a resource for livestock and rehabilitation of degraded lands. Proceedings of the International Workshop on Halophytes for reclamation of saline wastelands and as a resource for livestock problems and prospects. Nairobi, Kenya, 22-27 November 1992. Kluwer Academic Publishers.

Watson, M.C., 1990. Atriplex species as irrigated forage crops. Agriculture, Ecosystems and Environment 32, 107-118.

Wilcock, T.E., Van Niekerk, W.A., Rethman, N.F.G. \& Coertze, R.J., 2004. A comparison of Cassia sturtii, Tripteris sinuatum and Sutherlandia microphylla: three fodder shrubs applicable to revegetation of degraded rangeland in the Northern Cape Province. S. Afr. J. Anim. Sci. 34 (Suppl. 1), 114-116. 